\title{
A formação crítica do leitor à reflexão dos fatores pragmáticos da textualidade na produção de fake news sobre o coronavírus: uma análise linguística textual
}

\author{
Natália Coêlho Bagagim* \\ Lucinalva de Almeida Silva** \\ Marcelo Silva de Souza Ribeiro***
}

\begin{abstract}
Resumo
Em meio à pandemia do novo coronavírus (covid-19), a explosão de informações nas mídias a respeito da doença tem intensificado a produção e disseminação de notícias falsas. Dessa forma, este trabalho, apoiado na abordagem qualitativa de pesquisa, objetivou analisar a formação crítica do leitor a partir da reflexão sobre os fatores pragmáticos da textualidade na produção de fake news sobre a covid-19. São objetos de análise três publicações sobre a cura do coronavírus mediante insumos caseiros. Essas publicações foram checadas pelo site do Ministério da Saúde e comprovadas como fake news. A pesquisa foi embasada na Linguística Textual sob os fundamentos teóricos de Costa Val (1991, 2008), Koch e Travaglia (1993, 2015), Marcuschi (2008), Koch (2014), Koch e Elias (2008), Rodrigues et al. (2009), Santaella (2018), Leite (2019), Galhardi et al. (2020) e Bauman (2001) sobre fake news e sua intensificação. Constatou-se que a formação crítica dos leitores ainda é limitada, pois os produtores de fake news
\end{abstract}

* Universidade Federal do Vale do São Francisco (UNIVASF). Mestre em Letras (UFCG). Pós-graduanda em Metodologias Ativas (UNIVASF). Professora permanente na Educação Básica (Ouricuri/PE). Professora Substituta do Instituto Federal do Sertão Pernambucano (IFSERTÃOPE - CPZR). ORCID: https://orcid.org/0000-0002-9807-4950.

** Universidade Federal do Vale do São Francisco (UNIVASF). Mestre em Educação (UPE). Especializações: Educação, Contemporaneidade e Novas Tecnologias (UNIVASF), Gestão e Coordenação em Educação (UPE), Metodologia do Ensino de Língua Inglesa (INTA). Professora permanente na Educação Básica (Afrânio/PE, Santa Filomena/PE). ORCID: https://orcid. org/0000-0002-0389-5335.

*** Universidade Federal do Vale do São Francisco (UNIVASF). Doutor em Ciências da Educação (UNIVERSITÉ DU QUÉBEC À MONTRÉAL). Especializações: Educação Especial (UFAL), Educação a Distância (SENAC), Produção de Mídias para a Educação On-line (UFBA). Professor permanente no Colegiado e Mestrado de Psicologia (UNIVASF) e no Mestrado em Educação (UPE) em Petrolina/PE. ORCID: https://orcid.org/0000-0003-1196-7383. 
se valem dos fatores pragmáticos da textualidade para atribuir sentidos ao que se enuncia sobre o coronavírus e ganham à cooperação do leitor na aceitação dos seus conteúdos. Logo, essa interação autor/texto/leitor dificulta o combate à crise sanitária no Brasil.

Palavras-chave: Coronavírus. Fake news. Linguística Textual.

\title{
The critical formation of the reader to reflect on the pragmatic factors of textuality in the production of fake news about the coronavirus: a linguistic textual analysis
}

\begin{abstract}
In the midst of the pandemic of the new coronavirus (covid-19), the explosion of information in the media about the disease has intensified the production and dissemination of fake news. Thus, this work, supported by the qualitative research approach, aimed to analyze the critical formation of the reader to the reflection of the pragmatic factors of textuality in the production of fake news about covid-19. Three publications on coronavirus cure through homemade inputs are analyzed. These publications were checked by the Ministry of Health website and confirmed as fake news. The research was based on Textual Linguistics under the theoretical foundations of Costa Val (1991, 2008), Koch and Travaglia (1993, 2015), Marcuschi (2008), Koch (2014), Koch and Elias (2008), Rodrigues et al. (2009), Santaella (2018), Leite (2019) and Galhardi et al. (2020), Bauman (2001) on fake news and its intensification. It was found that the critical training of readers is still limited, as the producers of fake news use the pragmatic factors of textuality to attribute meanings to what is stated about covid-19 and gain the cooperation of the reader in the
\end{abstract}


acceptance of its contents. Therefore, this interaction among author / text / reader makes it difficult to combat the health crisis in Brazil.

Keywords: Coronavírus. Fake news. Textual linguistics.

Recebido em: 06/07/2021 // Aceito em: 04/10/2021. 


\section{Introdução}

O advento das redes sociais, na sociedade contemporânea, possibilitou ao indivíduo diversas formas de interações sociais que promovem novas significações e ressignificações de enunciar e entender o mundo por meio da linguagem. Contudo, com a modernidade midiática priorizando a "comunicação líquida," na qual "a instantaneidade faz com que cada momento pareça ter capacidade infinita; e a capacidade infinita significa que não há limites ao que pode ser extraído de qualquer momento - por mais breve e 'fugaz' que seja [...]” (BAUMAN, 2001, p. 145), manifestou-se também, um dos maiores problemas do século XXI: o fenômeno das fake news (notícias falsas), que espalham os seus discursos intencionais enganosos com facilidade e rapidez dentro de contextos situacionais, sobretudo por meio das mídias digitais sociais, haja vista que as fake news objetivam influenciar as crenças das pessoas a fim de manipulálas politicamente ou socialmente em prol de interesses escusos (SANTAELLA, 2018), em um panorama no qual fatos objetivos são menos influentes do que apelos emocionais fundamentados em opiniões fabricadas pretensiosamente.

Diante disso, em meio à crise sanitária do coronavírus, em que notícias relacionadas à pandemia dominaram a mídia nacional e internacional, a produção de notícias falsas se intensificou. Consequentemente, a sua disseminação de forma incontrolável e danosa tem provocado nos indivíduos desconfiança e perda de parâmetros no sentido de distinguir o que é informação falsa e verdadeira, fomentando a desinformação.

Bauman (2001) evidencia que, na sociedade da pósverdade, é primordial que o leitor desenvolva a capacidade do 
A formação crítica do leitor à reflexão dos fatores pragmáticos da textualidade na produção de fake news sobre o coronavírus: uma análise linguística textual

pensamento crítico, sobretudo diante de conteúdos recebidos pelas redes sociais, a fim de que por meio da reflexão, ele possa perceber os padrões da textualidade utilizados pelos enunciadores de fake news para atingir as suas metas preestabelecidas e não compactuar com a disseminação da desinformação. Beaugrande (2004 apud RODRIGUES, 2009) destaca que o texto só existe a partir do momento que alguém o processa; assim, as fake news como produto, não textualizadas, seriam apenas um artefato sem sentido publicado nas redes sociais. Todavia, quando ocorre o ato da interação autor/texto/leitor, elas se transformam e ganham dimensão expandindo-se exponencialmente em detrimento de um fato.

Assumindo, portanto, essa problemática, este trabalho propõe discorrer sobre os fatores pragmáticos da textualidade que são utilizados na produção de fake news sobre o coronavírus. Nesse sentido, as fake news podem ser entendidas como um gênero linguístico-discursivo presente em atos de comunicação feitos por meio da fala e da escrita que refletem crenças negativas, com diversas intencionalidades, dentre elas: a de comprometer a credibilidade da informação acerca do coronavírus e a de manipular o pensamento humano em prol da crença no que lhe é proposto.

É importante ainda situar que este trabalho decorre de uma pesquisa cujo objetivo geral foi analisar a formação crítica do leitor a partir da reflexão sobre fatores pragmáticos da textualidade na produção de fake news sobre o coronavírus. A análise do corpus seguiu procedimentos qualitativos, uma vez que traçou a interpretação a respeito do modo como os fatores pragmáticos da textualidade foram utilizados pelos enunciadores de fake news para alcançar os seus objetivos de convencimento 
do leitor, impulsionando-o à apatia e à validação de fake news. O objeto da pesquisa foi constituído de três publicações sobre a cura do coronavírus mediante insumos caseiros. Essas publicações foram checadas pelo site do Ministério da Saúde (MS) e comprovadas como fake news.

Este estudo está embasado na Linguística Textual e apresenta contribuições de teóricos como Costa Val (1991, 2008), Koch e Travaglia (1993, 2015), Marcuschi (2008), Koch (2014), Koch e Elias (2008), Rodrigues et al. (2009), Santaella (2018), Leite (2019), Bauman (2001), Freitas et al. (2020) e Galhardi et al. (2020).

\section{Fake news: intensificação da desinformação sobre o Co- ronavírus}

A massificação das Tecnologias da Informação e Comunicação (TICs) tem permitido, de modo desmesurado, a multiplicação de produtores e consumidores de informações na internet, uma vez que qualquer um pode produzir e consumir todo tipo de conteúdo. Com isso, o leitor tem substituído o jornalismo tradicional pela dinâmica das mídias alternativas e das redes sociais. Essa dinamização de interação tem se tornado um espaço fértil para a produção e disseminação de informações equivocadas e repletas de conteúdos falsos, que fortalecem uma rede de desinformação de forma incontrolável, haja vista que um post no Twitter ou Facebook, além do compartilhamento de uma postagem no WhatsApp, tem potencial avassalador de comoção da opinião pública, podendo ganhar seis vezes maior dimensão que um fato. 
A formação crítica do leitor à reflexão dos fatores pragmáticos da textualidade na produção de fake news sobre o coronavírus: uma análise linguística textual

Diante dessa "nova" realidade, expressões como "pósverdade" e "fake news" têm ganhado notoriedade, sobretudo a partir de 2016, ano em que dois fenômenos de grande repercussão política internacional ganharam visibilidade nas mídias digitais, a citar: o processo de saída do Reino Unido da União Europeia (Brexit) e a eleição de Donald Trump para presidente dos Estados Unidos da América. Em meio à ocorrência desses fenômenos, a produção e circulação de informações de modo exponencial, sem a organização, verificação, seleção e exclusão discursivas, permearam as redes sociais e as mídias com o intuito de manipular as emoções e de realizar influências, com vistas a moldar a opinião pública. No Brasil, a enunciação e circulação de notícias falsas se fortalecem a cada dia, especialmente diante de assuntos polêmicos e de grande repercussão, no âmbito político, artístico, social, econômico e de saúde pública.

Leite (2019) esclarece que as fake news ou "notícias falsas" resultam de um subproduto de comunicação de massa que não é novo, pois registros históricos datam as fake news desde o século VI, em que o escritor Procopio, intitulou um texto secreto chamado anedokta, o qual arruinou o imperador Justiniano e outros. Contudo, na contemporaneidade, o destaque maior das fake news são os meios digitais que possibilitam o grande poder de multiplicação vertiginosa de conteúdos que contaminam e comprometem os processos de informação e formação dos indivíduos para a cidadania e para a democracia.

Dentre as inúmeras informações falsas que circulam nos meios digitais, devem-se destacar as publicações falaciosas e repletas de desinformação advindas do surto do coronavírus, em que o leitor, impactado pela tensão provocada pela dimensão pandêmica de uma doença que apresentou ao país e ao mundo 
severos impactos epidemiológicos, sociais e políticos, passa a crer em discursos salvacionistas e leigos no que se refere à comprovação científica, o que coloca em risco à saúde pública.

Santos (2020) destaca que as notícias falsas espalharamse no mundo tendo a pandemia como seu principal alvo e que a OMS vem tratando esse problema como uma "infodemia," uma intensa "onda" de desinformação advinda da quantidade excessiva de informações inseguras e sem comprovação científica que dificultaram as soluções para o problema em questão, ocasionando um imbróglio desinformativo que afeta a saúde mental dos indivíduos em isolamento. As fake news acerca da coronavírus propagadas pelas mídias digitais foram produzidas com a intenção de induzir o leitor a crer que a doença não era grave e, com isso, colocaram em risco os cuidados com a saúde, o que poderia levar um indivíduo à morte. Galhardi et al. (2020) destacam que as notícias falsas também são identificadas nas mensagens de determinadas pessoas detentoras de poder como o presidente de extrema direita do Brasil, ${ }^{1}$ que nega a gravidade da doença em seus discursos, e como o ex-presidente dos Estados Unidos, ${ }^{2}$ que, além de negar a doença, em um dos seus discursos, indicou como tratamento, sem comprovação cientifica, a ingestão de desinfetante como meio eficaz de matar o vírus. ${ }^{3}$ Esses discursos de autoridades são possuidores de confiança diante da população e fortaleceram a adesão às fake news, sendo que a grande mídia, responsável por noticiar

1 Discursos falsos identificados nas mensagens de pessoas detentoras de poder como o presidente do Brasil. Disponível em: https://www.aosfatos.org/noticias/bolsonaro-nega-orientacoes-da-ciencia-e-distorce-informacoes-para-minimizar-pandemia. Acesso em: 20 maio 2021.

2 Discurso negacionista do ex-presidente dos Estados Unidos acerca da covid-19. Disponível em: https:/g1.globo.com/bemestar/ coronavirus/noticia/2020/02/29/trump-diz-que-nao-ha-motivo-para-panico-apos-1a-morte-por-coronavirus-nos-eua.ghtml. Acesso em: 21 maio 2021.

3 Discurso do ex-presidente dos Estados Unidos com orientação de ingestão de desinfetante como meio eficaz de matar o vírus. Disponível em: https:/g1.globo.com/mundo/noticia/2020/04/24/trump-fala-em-injecao-de-desinfetante-contra-coronavirus-emedico-rebate-irresponsavel-e-perigoso.ghtml. Acesso em: 22 maio 2021. 
A formação crítica do leitor à reflexão dos fatores pragmáticos da textualidade na produção de fake news sobre o coronavírus: uma análise linguística textual

seus discursos em virtude de serem de interesse público, acaba redimensionando seu potencial desinformativo negacionista, sem empatia pelos milhares de óbitos que se acumulam Brasil afora. Todavia, o foco maior das notícias falsas são as plataformas digitais.

Galhardi et al. (2020) apontam em pesquisa realizada entre 17 de março de 2020 a 10 de abril, período em que as fake news sobre o coronavírus foram mais produzidas e disseminadas, em detrimento da situacionalidade do surgimento recente da pandemia, que $73,7 \%$ das mensagens falsas circularam pelo aplicativo de mensagem instantâneo WhatsApp, 15, 8\% pelo Facebook e 10,5\% pelo Instagram, redes sociais com alcance exponencial. Dentre as fake news mais divulgadas, predominavam, com $65 \%$, as que ensinavam métodos caseiros para prevenir o contágio do coronavírus e as notícias falsas relacionadas aos métodos caseiros para a cura da doença, com $20 \%$.

\section{A produção de fake news a partir dos fatores pragmáti- cos discursivos da textualidade}

No Brasil, o estudo mais aprofundado dos padrões da textualidade ganhou visibilidade na década de oitenta a partir de pesquisas da Linguística Textual. Estes padrões foram introduzidos por Robert-Alain de Beaugrande e Wolf Gan Dessler, em 1981, no livro Introduction to text linguistics. De acordo com os autores, todo texto pode ser definido como uma ocorrência comunicativa que reúne/estabelece sete padrões constitutivos da textualidade, que são: coesão, coerência, intencionalidade, aceitabilidade, informatividade, 
situacionalidade e intertextualidade (RODRIGUES et al., 2009).

Essa perspectiva teórica da textualidade se definiu no Brasil a partir das pesquisas e conceituações de Koch e Travaglia, em 1989, na primeira edição do livro Texto e coerência. Para eles, o que faz de uma sequência linguística um texto é a textualidade, isto é, a constituição do texto pelo enunciador e sua interpretação pelo leitor. Dessa forma, diante da vertente enunciativa da Linguística Textual, os padrões da textualidade passaram a ser incorporados à luz dos gêneros textuais que circulam socialmente, dentre eles as fake news, pois todo tecido verbal é visto com uma finalidade discursiva dentro do processo de produção e interpretação.

Costa Val (1991), complementarmente, elucida que toda unidade textual se constrói no aspecto sociocomunicativo, por meio dos fatores pragmáticos (intencionalidade, aceitabilidade, informatividade, situacionalidade e intertextualidade); dos aspectos semânticos, por meio da coerência; do aspecto formal, por meio da coesão. Assim, dada à relevância dos padrões da textualidade para a compreensão da constituição da enunciação de textos comunicacionais e interacionais como as fake news, o objeto de estudo desses fatores para a discussão aqui apresentada constituiu-se, de modo delimitado, dos fatores pragmáticos da textualidade, por se estabelecerem de modo direto na enunciação das fake news e na recepção delas pelo leitor, por meio da atuação informacional, haja vista que o sentido do texto não se encontra no texto e não é dado pelo texto, mas é produzido pelo interlocutor a cada interação e uso da língua (COSTA VAL, 2008).

Nessa vertente, é pertinente ressaltar que um autor escreve o texto com um determinado propósito de comunicação, 
A formação crítica do leitor à reflexão dos fatores pragmáticos da textualidade na produção de fake news sobre o coronavírus: uma análise linguística textual

projetando a relação com um leitor, por meio da atuação conjunta de uma complexa rede de fatores de ordem situacional, cognitiva, sociocultural e interacional que possam construir determinado sentido nele (KOCH, 2014). Dessa forma, o produtor que enuncia fake news produz textos tencionando influenciar de várias formas os interlocutores: para atraí-los e para que suas postagens se tornem virais, atraindo mais visitantes, usandoos, em parte, como novos propagadores dos seus conteúdos por meio do compartilhamento em redes sociais como o Facebook.

Nesse sentido, o propósito de um autor ao produzir um texto que cause efeito sobre um interlocutor é chamado de intencionalidade e se refere "ao modo como os emissores usam textos para perseguir e realizar suas intenções, produzindo, para tanto, textos adequados à obtenção dos efeitos desejados [...]" (KOCH; TRAVAGLIA, 2015, p. 97). Contudo, a intenção de um enunciador de fake news não é alcançada na produção do texto, mas construída pelo leitor na interação, pois "a intenção do autor é altamente dependente das condições oferecidas por seu interlocutor, entre as quais sua maior ou menor disposição para aceitar o texto [...]" (RODRIGUES et al., 2009, p. 80). Assim, a disseminação de notícias falsas sobre a covid-19 se estabeleceu por intermédio da cooperação e interação entre autor/ texto/leitor (KOCH; ELIAS, 2008), haja vista que o texto falso planejado pelo autor, repleto de inverdades e interesses escusos, alcançou a aceitabilidade do leitor que o acessou, leu, ou não leu, validou e compartilhou, com a utilização exponencial das redes sociais, fenômeno que tem potencializado a proliferação da desinformação, a partir da presença maciça dos sujeitos nesses espaços virtuais. 
A "aceitabilidade constitui a contraparte da intencionalidade [...]" (KOCH; TRAVAGLIA, 2015, p. 98) e está relacionada à atitude do receptor do texto, constituindo-se em relações mútuas cooperativas, pois, ao se alcançar a intencionalidade, a aceitabilidade surge como consequência. Em vista disso, destacase a importância da leitura crítica/ativa do leitor diante dos diferentes textos que circulam socialmente nas mídias digitais, já que a leitura deve ser vista não como extração de informações e desinformações, mas como atividade que implica estratégias de seleção, antecipação, inferência e verificação (KOCH; ELIAS, 2008). Diante do mencionado, é primordial que o leitor atente ao que está sendo proposto pelo texto, levante hipóteses, processe, critique e questione as intenções do autor a fim de que se possa permitir ou refutar as informações que lhe são apresentadas. Nessa vertente, diante da explosão de informações nas mídias digitais na contemporaneidade, é fundamental a reflexão e análise dos textos, sobretudo os midiáticos. Santaella (2018, p. 40) apresenta algumas orientações que instruem o leitor a acionar o senso crítico antes de aceitar um texto que foi premeditado de acordo com as intenções pelo autor:

(a) olhar com atenção e atentar para a confiabilidade das fontes;

(b) ir além das chamadas e reconhecer sinais de sensacionalismo;

(c) procurar por outras fontes;

(d) verificar os fatos, sua data de publicação;

(e) conferir se o conteúdo afeta seus preconceitos;

(f) reconhecer quando se trata de brincadeira e conferir se vem de uma fonte piadista.

(SANTAELLA, 2018, p. 40)

Ao apontar essas orientações, a autora vislumbra demonstrar ao leitor que o foco do texto não está na superfície, 
A formação crítica do leitor à reflexão dos fatores pragmáticos da textualidade na produção de fake news sobre o coronavírus: uma análise linguística textual

nem na intencionalidade subjetiva do autor, mas na interação autor/texto/leitor. Por isso, diante de textos escusos e estranhos, o papel do leitor crítico é de suma importância, uma vez que ele tem o poder de reflexão sobre aquilo que lê. Assim, quando o leitor se permite a dúvida, ele busca checar, verificar e analisar o conteúdo que lhe é apresentado. Por intermédio disso, as chances são maiores de ele identificar a intenção maliciosa do autor do texto repleto de fake news e não cooperar com esse tipo de conteúdo, tornando-se crítico e responsivo acerca do que consome e de que maneira o faz.

No que concerne à produção textual de fake news, é importante apontar os critérios estratégicos dos seus produtores que constroem os textos em consonância com a situação específica de comunicação. Nessa linha, "a situacionalidade não só serve para interpretar o texto ao seu contexto interpretativo, mas também para orientar a própria produção [...]" (MARCUSCHI, 2008, p. 128). Com isso, o autor produz as fake news baseado em contextos enunciativos de repercussão midiática e as planeja de modo que elas se apresentem como relevantes para a sociedade, primando por ativar emoções.

Costa Val (1991) enfatiza que o interesse do recebedor pelo texto vai depender do seu grau de informatividade, grau que, para ser bom precisa atender a uma suficiência de dados, uma vez que um texto precisa apresentar todas as informações necessárias para que seja compreendido com o sentido que o produtor pretende. Nesse viés, um autor de notícia falsa oferece em seu texto, propositalmente, discursos de autoridades, dados estatísticos, etc., com o intuito de fazê-lo ser compreendido como verdadeiro e aceito pelo receptor. O receptor, por sua vez, desprovido de formação crítica processa o que é enunciado e 
coopera com a desinformação, validando-o.

Koch (2014) ressalta que todo texto é um objeto heterogêneo e dialoga, retoma, alude ou se opõe a outros textos. Diante disso, observa-se que o fato de as notícias falsas serem produzidas a partir de um contexto alimenta, em parte, a aceitação do leitor da desinformação prestada pelo enunciador, porque o leitor acredita erroneamente que aquele texto é um complemento do que foi noticiado.

Diante desse cenário, é primordial que o leitor atente para a textualidade apresentada e busque realizar pesquisas antes de confiar no conteúdo. Há diversos "sites checadores" que investigam e validam a veracidade das notícias que circulam nas redes sociais. Dentre eles, a Agência Lupa, ligada ao site Folha de S. Paulo; ${ }^{4}$ o Fato ou Fake, criado pelo grupo Globo; ${ }^{5}$ o E-Farsas, ${ }^{6}$ um dos sites de checagem de notícias mais antigo, além de tantos outros. Assim, a checagem das informações dos textos em rede deve ser uma responsabilidade do leitor, que precisa se questionar a respeito do conteúdo: O quê? Quem? Para quem? Onde? Quando? Como?

\section{Trilha do método}

Neste trabalho, adotou-se a pesquisa documental, de natureza qualitativa. Evangelista (2012) diz que a pesquisa documental permite ao pesquisador analisar as pistas, sinais, vestígios do documento a fim de que se possam compreender os significados dos materiais encontrados. Desenvolveuse, portanto, uma análise pragmática discursiva textual de

\footnotetext{
4 Disponível em: https://piaui.folha.uol.com.br/lupa. Acesso em 24 maio 2021

5 Disponível em: https://g1.globo.com/fato-ou-fake. Acesso em 25 maio 2021.

6 Disponível em: https://www.e-farsas.com. Acesso em 26 maio 2021.
} 
A formação crítica do leitor à reflexão dos fatores pragmáticos da textualidade na produção de fake news sobre o coronavírus: uma análise linguística textual

publicações de fake news sobre o coronavírus disseminadas nas redes sociais que foram repostadas e desmentidas pelo site do Ministério da Saúde (MS - antigo.saude.gov.br).

Pádua (1997, p. 62), complementarmente, enfatiza que "pesquisa documental é aquela realizada a partir de documentos, contemporâneos ou retrospectivos, considerados cientificamente autênticos (não fraudados); tem sido largamente utilizada nas ciências sociais.". Nesse contexto, as publicações checadas e comprovadas pelo site do MS como falsas, possibilitam a análise dos fatores pragmáticos discursivos textuais presentes nas fake news.

É importante destacar que, com o intuito de combater as fake news relacionadas à saúde, o MS, no site (antigo.saude. gov.br), disponibiliza número de WhatsApp para a população enviar, para a realização da checagem, mensagens recebidas por meio de redes sociais que contenham postagens duvidosas. Após a verificação, o site faz "Repost" da notícia falsa e notifica que é fake news orientando os cidadãos a não realizarem o compartilhamento. O site realiza o trabalho de checagem dos conteúdos e oferece serviços de informação segura a população desde agosto de 2018. Todavia, desde março de 2020, a demanda de checagem de mensagens instantâneas circuladas na internet tem ganhado grandes proporções, promovendo uma infodemia.

A análise do corpus seguiu procedimentos qualitativos, uma vez que traçou a interpretação do modo como os fatores pragmáticos da textualidade foram utilizados pelos enunciadores de fake news. O objeto da pesquisa foi constituído de três publicações sobre a cura do coronavírus mediante insumos caseiros: "Óleos essenciais curam o coronavírus", "Uísque e mel curam o coronavírus" e "Coronavírus pode ser curado 
com tigela de água e alho recém-fervida". O critério de escolha dessas postagens se relaciona com a propagação em massa de fake news sobre curas milagrosas por meio de remédios caseiros do coronavírus, no período de março a abril de 2020, e com o impacto instantâneo que essas postagens causavam a população. A seleção das publicações ocorreu no período supracitado, após verificação realizada pelo MS, atestando sua falsidade.

\section{Resultados, análise e discussão dos dados}

A celeridade das interações midiáticas possibilitou, em tempos de pandemia, a enunciação e a propagação em massa de inúmeras fake news. Percebeu-se que elas foram produzidas e disseminadas nas redes sociais de forma tendenciosa, apresentando curas milagrosas do coronavírus, valendo-se da aflição das pessoas pela contaminação e de virem a óbito, pois os médicos e a comunidade científica não tinham uma solução de cura para o vírus neste período (março-abril de 2020). Diante do contexto, os enunciadores de fake news se apropriaram do momento para alcançar as suas finalidades discursivas, promovendo estratégias que favoreciam o efeito de seriedade do conteúdo por meio de fotos, vídeos, discurso direto, etc. Observou-se também que, o produto textual - fake news sobre a cura do coronavírus - circulou nas mídias, por meio da interação com o leitor, utilizando-se de linguagem verbal e não verbal, de modo estratégico para condicioná-lo como verdadeiro. Dentre as principais fake news que foram propagadas no período, destacase, inicialmente para a análise, a notícia falsa "Óleos essenciais curam o coronavírus" (Figura 1). 
A formação crítica do leitor à reflexão dos fatores pragmáticos da textualidade na produção de fake news sobre o coronavírus: uma análise linguística textual

\section{Figura 1 - Óleos essenciais combatem o coronavírus}

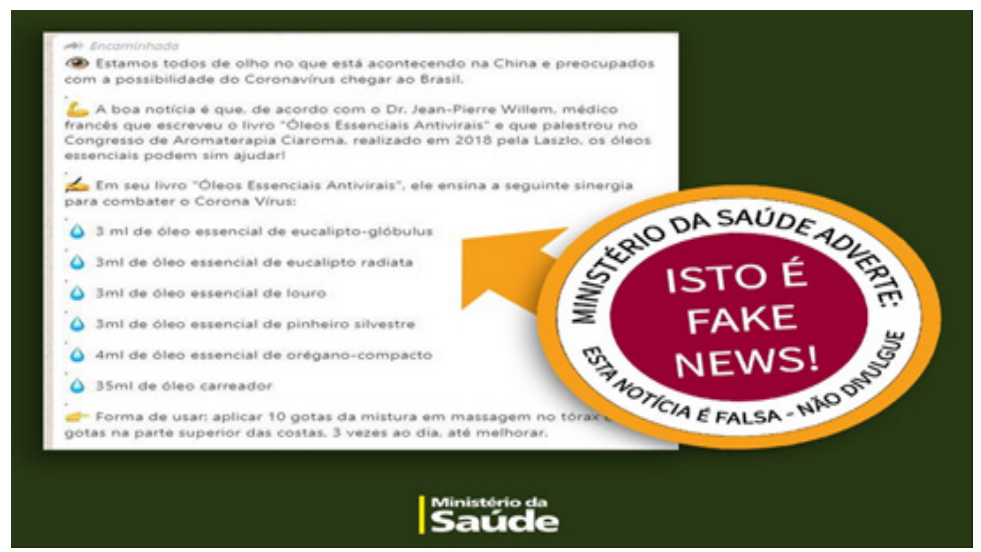

Fonte: Site do Ministério da Saúde

Observou-se que a notícia falsa (Figura 1) foi planejada, uma vez que são perceptíveis diversas intencionalidades do anunciante. Constatou-se que uma das principais intenções era manipular a crença do leitor, haja vista que a população em geral faz uso de insumos caseiros para curas de enfermidades simples. Assim, diante da confiança do leitor nos óleos essenciais, o enunciador de fake news avaliou a situacionalidade como propícia para propagar que essa substância natural também curava o coronavírus.

Em outras circunstâncias de doença - câncer, por exemplo, esse texto (Figura 1) não teria ganhado relevância, mas, em meio à situação de enunciação - doença viral -, o texto se mostrou pertinente e de grande aceitação. Koch e Travaglia (1993) destacam que o produtor e o leitor agem como se o texto fosse coerente, numa atitude cooperativa, visto que o enunciador já produz a notícia falsa de modo que ela faça sentido e visto que o leitor promove essa produção como algo feito para ter sentido - por isso esse tipo de conteúdo é disseminado de modo 
vertiginoso. Ademais, para convencer o leitor e causar efeitos positivos intencionais, o autor do texto (Figura 1) fez uso de discursos de autoridade, mencionando que o médico francês, Dr. Jean-Pierre Willem, afirmou que os óleos podem ajudar e, no livro escrito por ele, "Óleos Essenciais Antivirais", apresenta a receita para combater o coronavírus.

Nesse contexto, é importante frisar que o livro mencionado existe e que o médico citado pela postagem apresenta, de fato, óleos relacionados a outras doenças virais. Contudo, não há comprovação científica relacionada à cura do coronavírus, pois o livro foi publicado em 2018, um ano antes da pandemia, segundo dados da ficha técnica, exposta no site de vendas de livros das Lojas Americanas. Além disso, na época (março-abril 2020), não se tinha nenhuma medicação ou vacina comprovada de combate ao vírus. Na atualidade, as criações das vacinas que foram produzidas de combate ao coronavírus (Astrazeneca, Pfizer, Coronavac, Jassen ${ }^{7}$ e outras), não se relacionam com as informações do livro mencionado.

Constatou-se que o enunciador ajustou a informatividade do texto para permitir que o leitor construísse uma interpretação adequada a seu objetivo. Koch e Travaglia (1993) ressaltam que a informatividade exerce um importante papel na seleção e arranjo textual. Logo, o leitor alienado, robotizado, programado e predisposto a confirmar/rejeitar tudo que lê, sem refletir, que não questiona os conteúdos propagados nas mídias sociais é manipulado pelo enunciador de notícia falsa, uma vez que consome informações reguladas, triviais e subversivas. A partir disso, adota uma atitude que desrespeita a ética ao praticar ações como curtir, comentar e compartilhar notícias falsas.

\footnotetext{
7 Vacinas aprovadas pela ANVISA que combatem o coronavírus. Disponível em: https://agenciabrasil.ebc.com.br/saude/ noticia/2021-07/agencia-brasil-explica-vacinas-contra-covid-19-usadas-no-brasil. Acesso em: 31 maio 2021.
} 
A formação crítica do leitor à reflexão dos fatores pragmáticos da textualidade na produção de fake news sobre o coronavírus: uma análise linguística textual

Em virtude do que foi mencionado, é importante situar a importância da reflexão sobre a textualidade presente em um texto midiático, haja vista que, por meio dessa ação, é possível despertar o senso crítico acerca da checagem de fotos propagadas e de fatos noticiosos em circulação nas redes sociais, a partir da verificação do veículo, fonte, data, local de publicação, autoria, URL, etc. Com isso, a atividade de leitura deve implicar as estratégias de seleção, inferência e verificação (KOCK; ELIAS, 2008), sendo possível, assim, identificar a notícia falsa e não compactuar com seus enunciadores por meio de compartilhamentos e de aceitação do conteúdo como verdadeiro, já que a textualidade da fake news se efetiva a partir da aceitação do leitor.

Nessa vertente, outra enunciação de fake news que ganhou grande visibilidade e propagação nas redes sociais durante o período da pandemia foi a "Uísque e mel curam o coronavírus" (Figura 2).

\section{Figura 2 - Uísque e mel curam o coronavírus}

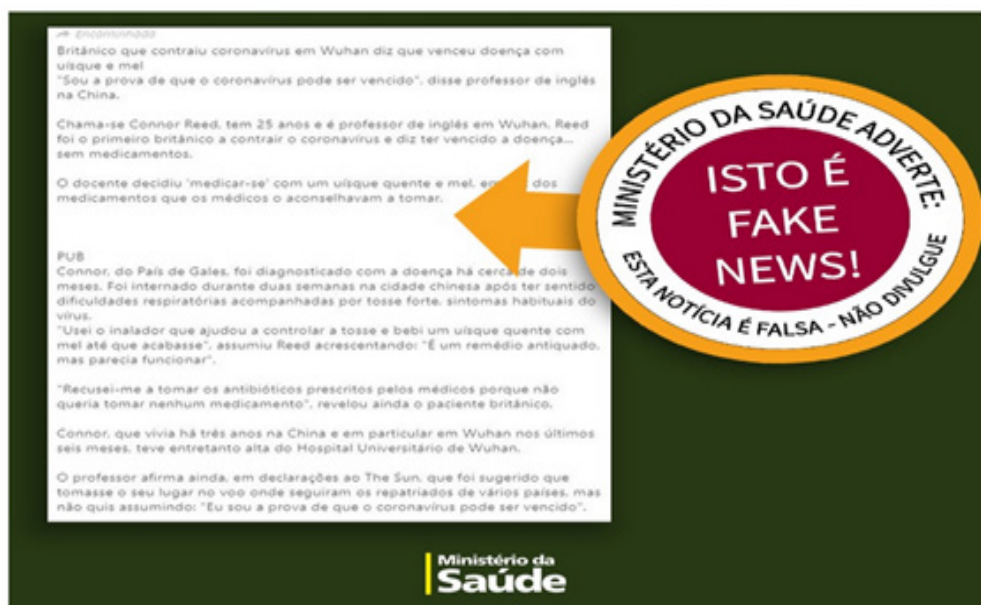

Fonte: Site do Ministério da Saúde 
Constatou-se que o autor da notícia falsa sobre a cura do coronavírus (Figura 2), por intermédio da ingestão de uísque quente e mel, considerou a situação - pandemia - relevante para divulgar, estrategicamente, a publicação. Observou-se também que o enunciador da notícia falsa em análise, realizou propositalmente escolhas textuais para convencer o leitor da veracidade das informações divulgadas, dentre elas, o discurso direto do suposto paciente curado. A intenção do enunciador da publicação analisada, aparentemente, era sensibilizar o leitor a acreditar na cura simples e milagrosa do vírus e fazêlo crer que esses remédios naturais são mais eficientes do que os medicamentos hospitalares. Nessa conjuntura, percebeu-se também que o produtor da notícia falsa se baseou nas experiências anteriores, isto é, no diálogo entre os textos para o convencimento do leitor, pois o uísque e mel são usados rotineiramente em várias culturas para a cura de resfriados simples. Então, o leitor é mobilizado pelo conhecimento intertextual, com base nas informações apresentadas e na situação pandêmica, alimenta as suas próprias crenças e aceita a publicação como verdadeira.

Além do que foi dito, constatou-se que, em meio à aceitação do leitor, ocorre o empoderamento da desinformação, em razão de o texto ter se tornado coerente mediante a interação autor/ texto/leitor (KOCH; ELIAS, 2008). Nessa direção, inferiu-se que a interação do leitor com o conteúdo falso enunciado demonstra insipiência de criticidade, porque qualquer indivíduo com uma formação crítica sólida, ou em construção, compreende as falhas na "informação" repassada, em virtude de ela não apresentar confiabilidade da fonte, link de acesso ao estudo realizado, data de publicação, etc.

$\mathrm{Na}$ era da pós-verdade, a formação crítica do leitor torna-se cada vez mais necessária diante da propagação dos textos midiáticos contemporâneos, em que o enunciador de 
A formação crítica do leitor à reflexão dos fatores pragmáticos da textualidade na produção de fake news sobre o coronavírus: uma análise linguística textual

fake news controla o leitor para realizar as suas intenções sociocomunicativas (KOCH; TRAVAGLIA, 2015), leitor que se torna um coenunciador de conteúdos falsos ao aceitar o que se propõe nas publicações falaciosas mediante o curtir, compartilhar, etc. Assim, diante da crescente enunciação de textos multimodais e midiáticos, um leitor crítico precisa ativar saberes que ultrapassem a decodificação do escrito, interpretando o que lê por meio de estratégias textuais como: buscar entender o objetivo do autor do texto, em que contexto situacional ele o produziu, quais efeitos ele pretende sobre o leitor, quais relações o texto estabelece com outro, o nível de informatividade presente no texto, etc. Logo, a contemporaneidade demanda um interlocutor apto a reconhecer a responsabilidade de sentidos na enunciação tendenciosa de caráter persuasivo e oportuno ao contexto, assumindo uma postura crítica em relação às fake news.

Dentre as várias fake news disseminadas sobre a cura do coronavírus, destaca-se também a ilustrada pela Figura 3: "Coronavírus pode ser curado com tigela de água e alho recémfervida".

Figura 3 - Coronavírus pode ser curado com tigela de água e alho recém-fervida

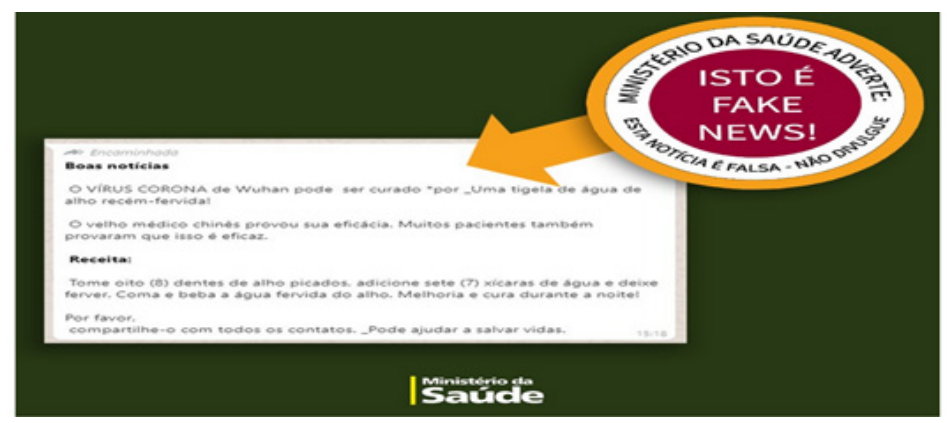

Fonte: Site do Ministério da Saúde 
Constatou-se que o enunciador da notícia falsa (Figura 3) desfrutou da situação - carência de medicamentos científicos de cura do coronavírus - para alcançar os seus principais objetivos: manipular a crença dos indivíduos e usá-los como propagadores de desinformação por meio do compartilhamento do conteúdo retratado. Dessa forma, visando obter a aceitação do leitor e, consequentemente, o compartilhamento do texto, o autor em questão apresenta em negrito a manchete "Boas notícias" e usa como estratégia discursiva a comprovação da receita por um médico chinês. A escolha "médico chinês" é usada estrategicamente para dar credibilidade ao enunciado linguístico e provocar a aceitabilidade. Além disso, outro recurso linguístico proposital se refere aos verbos no modo imperativo: "tome", "adicione", "deixe", "coma", "beba", com a intenção de estimular o leitor a crer que não é difícil curar a doença, se as instruções forem seguidas. Nesse contexto, a aceitabilidade do leitor aumenta, em virtude da ênfase do conteúdo em dialogar com suas crenças de cura por meio de insumos caseiros.

Observou-se ainda que o autor apela ao leitor e a sua cooperação por meio de termos como: "por favor", "compartilhe", "pode ajudar a salvar vidas". Essa apelação demonstra claramente a intenção do enunciador na propagação imediata da inverdade, mediante a tessitura textual de que esse conteúdo pode salvar vidas. Notou-se também que, ao usar os termos mencionados, o enunciador provoca a sensibilidade do leitor, atribuindo-lhe à responsabilidade pelo outro. Operase aqui uma relação intertextual em que o produtor associou propositalmente o conteúdo da notícia falsa à boa-fé das pessoas em ajudar o outro, valendo-se do momento de pandemia, no qual a cooperação foi tão evidenciada pelos principais veículos de comunicação e pelas autoridades sanitárias de saúde. 
A formação crítica do leitor à reflexão dos fatores pragmáticos da textualidade na produção de fake news sobre o coronavírus: uma análise linguística textual

Diante do exposto, o leitor insipiente e sem formação crítica coopera com o enunciador de fake news, pois não busca a checagem da informatividade do conteúdo recebido e compartilha de imediato a desinformação. Essa atitude pode causar inúmeras consequências, dentre elas a de fazer com que cidadãos que creem na solução milagrosa não busquem tratamento médico nos hospitais. Outra consequência é a falta de cuidado e de isolamento social, haja vista que o leitor passa a ser negacionista da gravidade da doença a partir de um viés de confirmação que vai ao encontro do que lhe é propício.

Logo, o produtor de fake news é um manipulador do leitor. Este último, carente de formação crítica e, desprovido do poder questionador dos conteúdos digitais se torna, inocentemente, um cooperador da mídia obscura, marionete, pois os diversos objetivos dos enunciadores de notícias falsas são somente alcançados por meio da mobilização conjunta em interações cooperativas: autor/texto/leitor (KOCH; ELIAS, 2008). Portanto, o leitor crítico é capaz de combater o poder malicioso dos enunciadores de fake news, visto que ele perceberá as intenções, os efeitos e a mobilização dos recursos linguísticos que o enunciador deseja provocar nos interlocutores. Em virtude dessa percepção, o leitor não aceitará "o jogo obscuro" disfarçado com "informações", planejado estrategicamente com base nos fatores pragmáticos, com vistas a estabelecer a coerência no que é proposto.

Logo, a promoção de um olhar atento e crítico pode ajudar de forma positiva no combate a enunciação de fake news a partir da análise da confiabilidade das fontes, da pesquisa em jornais idôneos, da verificação da data de publicação, da URL e do reconhecimento de manchetes alarmistas e sensacionalistas (SANTAELLA, 2018). 


\section{Considerações finais}

A Linguística Textual propicia a compreensão efetiva da textualidade dos diferentes gêneros discursivos que circulam socialmente, haja vista que a textualidade está interligada com os processos constitutivos dos enunciados escritos e das práticas de produção, compreensão e recepção dos textos, no qual o foco se concentra no leitor, no contexto em que a interação acontece.

Das discussões teóricas, ratifica-se que todo texto é produzido visando alcançar metas, e, no contexto da sociedade na era de pós-verdade, a enunciação de um texto tenciona que este seja entendido pelo leitor como se deseja. Dessa forma, pela análise empreendida, foi possível constatar que a formação crítica dos leitores ainda é limitada, pois os produtores de fake news se valem dos fatores pragmáticos da textualidade para atribuir sentidos ao que se enuncia sobre o coronavírus e ganha a cooperação do leitor na aceitação dos seus conteúdos. O enunciador de fake news sobre o coronavírus faz uso dos fatores pragmáticos da textualidade - intencionalidade, aceitabilidade, situacionalidade, intertextualidade e informatividade - para atribuir sentidos ao que se enunciava, com vistas a promover o alcance dos seus objetivos abscônditos diante do leitor, recorrendo ainda à infodemia para conduzir à produção de sentidos mediante o processo de interação autor/texto/leitor, agentes da comunicação.

Diante da grande repercussão de compartilhamentos das fake news sobre a cura do vírus, que tornou necessária a checagem das informações por parte do Ministério da Saúde em seu site, depreendeu-se que ocorreu a aceitabilidade do leitor. Assim, o texto passou a ser coerente, pois alcançou a tríade autor/texto/ 
A formação crítica do leitor à reflexão dos fatores pragmáticos da textualidade na produção de fake news sobre o coronavírus: uma análise linguística textual

leitor, a qual se apropriou ainda mais da infodemia gerada a partir da crise sanitária no Brasil, pois contribuiu com a desinformação e com os discursos negacionistas acerca da doença. Portanto, concluiu-se que a interação autor/texto/leitor dificulta o combate às fake news, sendo fundamental que o leitor se torne proficiente em ser um questionador dos conteúdos que circulam nas redes sociais, pois ele tem o poder efetivo de combater as fake news, dando a elas o seu devido lugar: a incoerência, já que o leitor que questiona e realiza a checagem das informações toma posse da verdade e, consequentemente, não aceita e nem compartilha a notícia falsa, fazendo com que ela perca o sentido e a coerência.

Logo, muitos outros estudos acerca da enunciação de fake news por meio dos fatores pragmáticos da textualidade ainda precisam ser realizados, a fim de se pensar em ações que possam promover a conscientização do leitor na interpretação crítica dos conteúdos, de modo que ele perceba o jogo estratégico dos recursos linguísticos usados pelo autor do texto para consecução dos seus objetivos, objetivos estes, obscuros e danosos à população.

\section{Referências}

ANTIGO SAUDE. Coronavírus pode ser curado por uma tigela de água de alho recém-fervida. 2020. Disponível em: https:// antigo.saude.gov.br/fakenews/46443-coronavirus-pode-sercurado-com-tigela-de-agua-de-alho-recem-fervida-e-fakenews. Acesso em: 25 maio 2021.

ANTIGO SAUDE. Uísque e mel contra coronavírus. 2020. Disponível em: https://antigo.saude.gov.br/fakenews/46281uisque-e-mel-contra-coronavirus-e-fake-news. Acesso em: 25 maio 2021. 
ANTIGO SAUDE. Óleos para combater coronavírus. 2020. Disponível em: https://antigo.saude.gov.br/fakenews/46277oleos-para-combater-coronavirus-e-fake-news. Acesso em: 25 de maio 2021.

BAUMAN, Z. Modernidade líquida. Rio de Janeiro: Jorge Zahar, 2001.

COSTA VAL, M. da G. Redação e Textualidade. São Paulo, Martins Fontes, 1991.

COSTA VAL, M. da G. Texto, textualidade e textualização. In: M. L, FERRARO et al. Experiência e prática de redação. Florianópolis, UFSC, 2008. p. 63-85.

Discursos falsos identificados nas mensagens de pessoas detentoras de poder como o presidente do Brasil. Disponível em: https://www.aosfatos.org/noticias/bolsonaro-nega-orientacoesda-ciencia-e-distorce-informacoes-para-minimizar-pandemia/>. Acesso em: 20 maio 2021.

Discurso negacionista do ex-presidente dos Estados Unidos acerca da Covid-19. Disponível em: https://g1.globo.com/ bemestar/coronavirus/noticia/2020/02/29/trump-diz-que-naoha-motivo-para-panico-apos-1 a-morte-por-coronavirus-noseua.ghtml. Acesso em: 21 maio 2021.

Discurso do ex-presidente dos Estados Unidos com orientação de ingestão de desinfetante como meio eficaz de matar o vírus. Disponível em:https://g1.globo.com/mundo/noticia/2020/04/24/ trump-fala-em-injecao-de-desinfetante-contra-coronavirus-emedico-rebate-irresponsavel-e-perigoso.ghtml. Acesso em: 22 maio 2021.

EVANGELISTA, O. Apontamentos para o trabalho com documentos de política educacional. In: R. M. DE LIMA ARAUJO; D. DO SOCORRO RODRIGUES (org.). A pesquisa em trabalho, educação e políticas educacionais. Campinas: Alínea, 2012. p. 52-71. 
A formação crítica do leitor à reflexão dos fatores pragmáticos da textualidade na produção de fake news sobre o coronavírus: uma análise linguística textual

FREITAS, A. R. R. et al. Análise da gravidade da pandemia de Covid-19. Epidemiol. Serv. Saúde, v. 29, n. 2, p. 1-5, abr. 2020. GALHARDI, C.P. et al. Fato ou Fake? Uma análise da desinformação frente à pandemia da Covid-19 no Brasil. Ciência \& Saúde Coletiva, v. 25, n. 2, p. 4201-4210, ago. 2020.

KOCH, I. V.; TRAVAGLIA, L. C. Texto e Coerência. 2. ed. São Paulo: Cortez, 1993.

KOCH, I, V. ELIAS, V.M. Ler e compreender os sentidos do texto. 2. ed. São Paulo: Contexto, 2008.

KOCH, I. 2014. O texto e a construção dos sentidos. 10. ed. São Paulo: Contexto, 2014.

KOCH, I. V.; TRAVAGLIA, L. C. A coerência textual. 18. ed. São Paulo: Contexto, 2015.

LEITE, A. P. M. A alfabetização midiática e informacional em tempos de fake news e o legado de Paulo Freire. In: P. R. PADILHA; J. ABREU (org.), Paulo Freire em tempos de fake news [livro eletrônico]: artigos e projetos de intervenção produzidos durante o curso da EaD Freiriana do Instituto Paulo Freire. São Paulo: Instituto Paulo Freire, 2019. p.12-18.

MARCUSCHI, L. A Produção textual, análise de gêneros e compreensão. 3. ed. São Paulo: Parábola Editorial, 2008.

PÁDUA, E. M. M. de. Metodologia da pesquisa: abordagem teórico - prática. 2. ed. Campinas: Papiros, 1997.

RODRIGUES, R. H. et al. Linguística textual. Florianópolis, LLV/CCE/UFSC, 2009.

SANTAELLA, L. A pós-verdade é verdadeira ou falsa? Barueri: Estação das Letras e Cores, 2018. 
SANTOS, C. Conheça as fake news mais absurdas já checadas sobre o coronavírus no mundo. 2020. Disponível em: https:// www.uol.com.br/tilt/noticias/redacao/2020/08/31/conheca-asfake-news-mais-absurdas-ja-checadas-sobre-o-coronavirus. $\mathrm{htm}$. Acesso em: 30 maio 2021.

Vacinas aprovadas pela ANVISA que combatem o coronavírus. Disponível em: https://agenciabrasil.ebc.com.br/saude/ noticia/2021-07/agencia-brasil-explica-vacinas-contra-covid19-usadas-no-brasil. Acesso em: 31 maio 2021 